\title{
Pesticide contamination of the coastline of Martinique
}

\section{Gilles Bocquené ${ }^{a^{*}}$ and Alain Franco ${ }^{\mathrm{b}}$}

aFREMER, Rue de l'lle d'Yeu, BP 21105, 44311 Nantes Cedex 3, France

baboratoire de Rouen, 49 rue Mustel, 76022 Rouen Cedex 3, France

*: Corresponding author : gilles.bocquene@ifremer.fr

\begin{abstract}
In January and February 2002, the presence of certain agricultural pesticides throughout the coastline of the Caribbean island of Martinique was investigated. The tropical climate of the French West Indies is suitable for banana production, which requires intensive use of pesticides. An inventory of all pesticides used on the island (compounds and tonnage) was compiled. Surveys and analyses revealed the presence of pesticides in the plumes of seven rivers. The organochlorine chlordecone and metabolites of aldicarb were detected at nearly all of the monitored sites, even though the use of chlordecone has been prohibited since 1993. Two triazines (ametryn and simazine) were also identified. The concentrations of carbamates and triazines detected in the water and sediment samples from Martinique are comparable to those reported for mainland France. Chlordecone concentrations in the sediment and particulate matter samples were, however, particularly high in the samples from Martinique. Toxicological implications are discussed. Of particular concern are the high levels of chlordecone (which is bioaccumulating and carcinogenic) and further monitoring of this compound is recommended, especially in fish and other sea-food products.
\end{abstract}

Keywords: Martinique island; Contamination; Pesticides; Triazines; Chlordecone; Aldicarb 


\section{Introduction}

Concerns regarding the intensive use of pesticides in agriculture and their associated ecotoxicological risks, has resulted in surveys and the development of monitoring networks for pesticides in the coastal areas of mainland France and its overseas Departments (Martinique and Guadeloupe islands, French Guyana, and Reunion island). Martinique, a $1,128 \mathrm{~km}^{2}$ tropical island in the French West Indies, is bordered by the Atlantic Ocean to the east and the Caribbean Sea to the west. The sea is never more than $12 \mathrm{~km}$ from any point in the island. Martinique has a volcanic, mountainous, and rocky landscape, and is characterized by abundant precipitation. The combination of high rainfall and high temperatures allows rapid crop growth.

In Martinique, the crops essentially consist of banana, sugar cane, and pineapple. The main crop is banana, with production in 1999 of approximately 300,000 tonnes. Sugar cane is a traditional crop and the production in 1999 was 200,000 tonnes. Pineapple production was of the order of 17,000 tonnes for the same year.

The tropical climate, whilst suitable for crop growth, is also favourable for pests and the use of nematicides, insecticides, fungicides, and herbicides, especially in banana plantations.

In the 1960's, most insecticides and nematicides used were organochlorines (OC). The main compounds were hexachlorocyclohexane $(\mathrm{HCH}$; marketed under the name lindane), aldrin, and dieldrin. During the 1970's, the efficacy of another OC, chlordecone (Curlone ${ }^{\circledR}$, Kepone $\AA$ ), was discovered. Although the persistence of this OC allowed the frequency of application to be reduced, problems associated with soil and aquatic resource contamination arose. The use of chlordecone in Martinique was prohibited in 1993.

In the 1980's, the first generation of organophosphorus pesticides, such as malathion, methyl parathion, disulfoton, and diazinon, were widely used in the island. At the beginning of the 1990's, these molecules were replaced by less ecotoxic organophosphorus compounds, such as cadusafos (Rugby ${ }^{\circledR}$ ), terbufos (Counter $®$ ), izasofos, and phenamiphos. During that same period, carbamates, such as aldicarb (Temik ${ }^{\circledR}$ ) and oxamyl $($ Vydate $\AA)$, were imported into Martinique. The use of aldicarb was also prohibited in 2003. The herbicides used in banana plantations in Martinique are triazines such as simazine (Gezatop $Z \bowtie)$, substituted ureas such as diuron (Karmex®), and quaternary ammonium compounds such as paraquat (R. Bix $®$ ), diquat (Reglone $®$ ), and glyphosate (Roundup $®$, Basta $\AA$ ).

Between 1977 and 2002, the amounts of pesticides imported to the Island appears to have been relatively constant (Table 1). There was, however, an increase in the imported tonnage of herbicides and fungicides while tonnage of insecticides decreased mainly because insecticide molecules are more active.

Table 1 : Pesticides imported into Martinique between 1977 to 2002, in metric tons of marketed formulation.

\begin{tabular}{|c|r|r|r|r|r|r|}
\cline { 2 - 7 } \multicolumn{1}{c|}{} & 1977 & 1986 & 1990 & 1996 & 1998 & 2002 \\
\hline Insecticides & 2,184 & 1,985 & 2,219 & 1,924 & 1,816 & 1,375 \\
\hline Herbicides & 217 & 120 & 339 & 493 & 459 & 526 \\
\hline Fungicides & 61 & 75 & 97 & 94 & 152 & 148 \\
\hline Miscellaneous & 24 & 92 & 61 & 51 & 295 & 331 \\
\hline Total & 2,486 & 2,272 & 2,716 & 2,562 & 2,722 & 2,382 \\
\hline
\end{tabular}

From 1994 to 1996, given the volumes of pesticides used, authorities initiated a series surveys to determine whether these compounds could be detected in surface waters.

The first data collected by the French Ministry of Environment (DIREN, 2001) and the French Ministry of Health (Direction de la Santé et du Développement Social de Martinique, DSDS, 2001), revealed widespread pesticide contamination of rivers and streams (discussed below).

Given the potential for transport of pesticides from rivers to the coastal zone we undertook a baseline investigation of pesticides and metabolites at 9 different sites located in the plumes of 7 rivers in Martinique in early 2002. 


\section{Materials and methods}

\subsection{Sampling}

In January and February 2002, water and sediment samples were collected and analysed for the presence of pesticides and some of their metabolites. Water and sediment samples were collected at the mouth of the Lorrain (1), Capot (2), Galion (3), François (4) and Cacao (5) rivers, located on the east coast of the island, and the Carbet (8) and Lézarde (9) rivers located on the west coast (Figure 1). Sampling was performed on the ebb tide within the plumes of rivers, at sites where salinity was approximately $0 \%$ (freshwater), except for samples collected at the mouth of the François river, where salinity reached $11 \%$ and in the Baie du Robert, where three samples were collected at different sites along a salinity gradient: in the estuary of the Cacao river in freshwater (5), approximately $30-\mathrm{m}$ away from the mouth of the river, where salinity reaches $25 \%$ (6) and in the middle of the bay, where salinity is 35\% (7) (Figure 1).

Figure 1 : Location of sampling sites in the plumes of rivers along the coastline of Martinique Island.

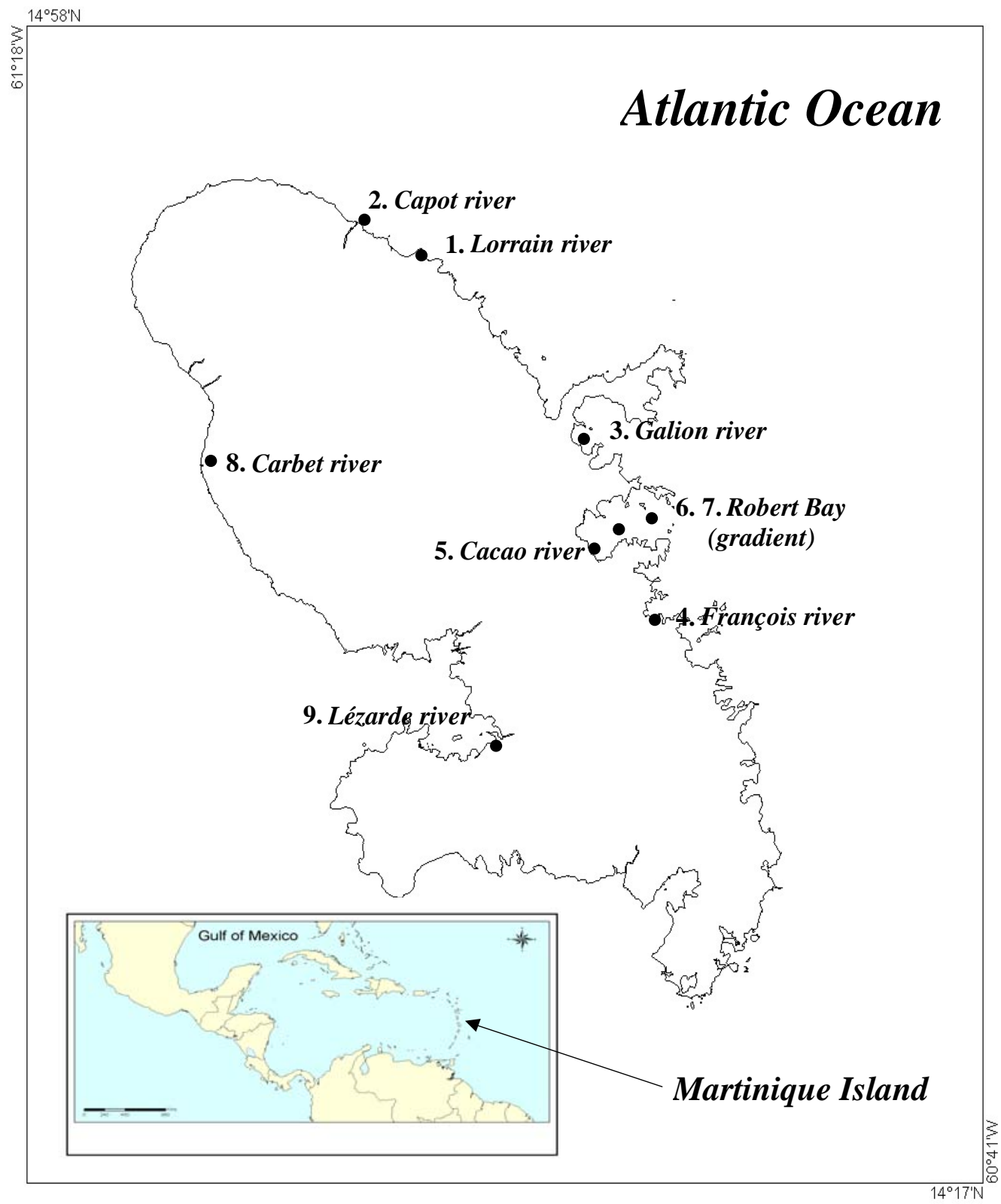




\subsection{Extraction procedure}

Five liters of water and $500 \mathrm{~g}$ of sediment were collected in acid cleaned dark glass bottles for water and in Teflon coated boxes for sediment at each site and returned to the laboratory. Water was vacuum filtered through glass fibre filters (GF/F, $\varnothing=47 \mathrm{~mm}, 0.7$ $\mu \mathrm{m}$ nominal porosity) to separate the particulate phase from the dissolved phase. Filters with particulate matter and sediments were immediatly frozen at $-20^{\circ} \mathrm{C}$. Sediments were freeze-dried just before extraction. Water was kept at $4^{\circ} \mathrm{C}$ until phase extraction. No surrogates were added to water nor sediments.

Half of this filtrate was acidified $(\mathrm{pH} \sim 3)$ with $\mathrm{H}_{2} \mathrm{SO}_{4}$ for optimal carbamate extraction while the remaining filtrate was not $\mathrm{pH}$ adjusted, for organophosphorus pesticide and triazine extraction.

Solid phase extraction (SPE) was carried out on the filtrates within two hours after the sampling. OASIS HLB (Waters, St Quentin en Yveline, France), a copolymer of pyrrolidone (hydrophilic) and divinylbenzene (lipophilic), was used as a SPE cartridge sorbent, as it allows efficient recovery and extraction of a broad spectrum of compounds. Recoveries cited by the sorbent manufacturers for aldicarb (carbamate), atrazine (triazine) and chlorpyrifos (organophosphate) are 86, 100 and 100\% respectively.

For GFF filters (i.e. the particulate phase), accelerated solvent extraction (ASE) was used, as developed by Dionex (Voisins le Bretonneux, France). This uses high temperatures and pressures to increase efficiency of extraction. A dichloromethane:acetone (50:50) mixture, followed by an extraction with an acetone:methanol mixture (50:50) was selected.

After lyophilization, sediment samples were also processed by ASE with a dichloromethane:acetone (50:50) mixture for organophosphorus and organochlorine pesticides, and an acetone:methanol mixture (50:50) for carbamates.

\subsection{Analyses}

The most widely used pesticides that might be present in the environment were selected for analysis (Table 2). For the dissolved phase, analyses were directed towards more soluble compounds such as some triazines, fungicides, aldicarb and its metabolites, as well as compounds with a more hydrophobic behaviour, such as some organophosphorus compounds. In the particulate phase and in sediments adsorption properties guided the focus of analyses: organophosphorus compounds, aldicarb (and its primary metabolites) and chlordecone. 
Table 2 : List of searched compounds and analytical methods (see the text for details)

\begin{tabular}{|l|c|}
\hline \multicolumn{1}{|c|}{ Compounds in filtered water } & Analytical method \\
\hline $\begin{array}{l}\text { Herbicides: } \\
\text { simazine, atrazine, terbumeton, secbumeton, } \\
\text { desmetryne, metribuzine, ametryn, prometryn, cyanazine, } \\
\text { terbuthylazine, terbutryne, desethylatrazine, } \\
\text { desethylsimazine }\end{array}$ & GC/NPD \\
\hline $\begin{array}{l}\text { Fungicides: } \\
\text { pyrifenox, cyproconazole, hexaconazole, flusilazole, } \\
\text { penconazole, propiconazole, tebuconazole }\end{array}$ & GC/NPD \\
\hline $\begin{array}{l}\text { Insecticides: } \\
\text { cadusafos, isazofos, terbufos, ethoprophos, phenamiphos } \\
\text { fipronil, } \\
\text { aldicarb, aldicarb-sulfone, aldicarb-sulfoxide }\end{array}$ & $\begin{array}{r}\text { GC/NPD } \\
\text { HPLC }\end{array}$ \\
\hline
\end{tabular}

\begin{tabular}{|c|c|}
\hline Compounds in particulate matter/ sediment & Analytical method \\
\hline $\begin{array}{l}\text { Insecticides } \\
\text { cadusafos, isazofos, terbufos, ethoprofos } \\
\text { phenamifos, } \\
\text { aldicarb, aldicarb-sulfone, aldicarb-sulfoxide } \\
\text { chlordecone }\end{array}$ & $\begin{array}{c}\text { GC/NPD } \\
\text { GC/NPD } \\
\text { HPLC/fluo Kok method } \\
\text { GC/ECD }\end{array}$ \\
\hline
\end{tabular}

Solvent extracts from eluted SPE cartridges and ASE were evaporated to near dryness (using a gentle stream of nitrogen), and the residue dissolved in $1 \mathrm{ml}$ solvent, the nature of which was specified by the chosen chromatographic technique. Analyses were performed as follows:

* Organophosphorus pesticides/triazine herbicides/triazole compounds. Gaschromatography with thermoionic nitrogen/phosphorus detector or ion trap mass spectrometer

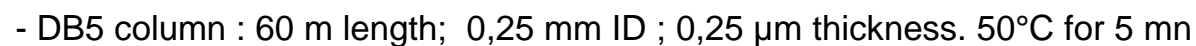
then up to $200^{\circ} \mathrm{C}\left(20^{\circ} \mathrm{C} \mathrm{m}{ }^{-1}\right), 200^{\circ} \mathrm{C}$ for $10 \mathrm{mn}, 300^{\circ} \mathrm{C}\left(30^{\circ} \mathrm{C} \mathrm{mn}{ }^{-1}\right)$ and $300^{\circ} \mathrm{C}$ for $5 \mathrm{mn}$. Splitless $250^{\circ} \mathrm{C}$ injector. $300^{\circ} \mathrm{C}$ detector. $1 \mu \mathrm{l}$ injected.

* Chlordecone. Gas-chromatography with electron capture detector or ion trap mass spectrometer column :

- DB5 $60 \mathrm{~m} ; 0,25 \mathrm{~mm} \mathrm{ID;} 0,25 \mu \mathrm{m}$ thickness. $60{ }^{\circ} \mathrm{C}$ for $4 \mathrm{mn}$ then up to $200^{\circ} \mathrm{C},\left(20^{\circ} \mathrm{C} \mathrm{mn}{ }^{-1}\right) 200^{\circ} \mathrm{C}$ for $20 \mathrm{mn}$ and $320^{\circ} \mathrm{C}\left(5^{\circ} \mathrm{C} \mathrm{mn}^{-1}\right)$ and $320^{\circ} \mathrm{C}$ for $10 \mathrm{mn}$. Splitless $250^{\circ} \mathrm{C}$ injector. $300^{\circ} \mathrm{C}$ detector. $1 \mu$ injected.

- DB1701 $60 \mathrm{~m} ; 0,25 \mathrm{~mm}$ ID; $0,25 \mu \mathrm{m}$ thickness. $60^{\circ} \mathrm{C}$ for $2 \mathrm{mn}$ then up to $200^{\circ} \mathrm{C},\left(20^{\circ} \mathrm{C} \mathrm{mn}{ }^{-1}\right) 200^{\circ} \mathrm{C}$ for $20 \mathrm{mn}$ and $280^{\circ} \mathrm{C}\left(5^{\circ} \mathrm{C} \mathrm{mn}{ }^{-1}\right)$ and $280^{\circ} \mathrm{C}$ for $16 \mathrm{mn}$. Splitless $250^{\circ} \mathrm{C}$ injector. $300^{\circ} \mathrm{C}$ detector. $1 \mu \mathrm{l}$ injected.

* Carbamates : high-performance liquid chromatography with diode array detector, and fluorescence detector after post column derivatization with PICKERING system (HPLC/ fluo. KOK method) (column : Supelco LC-8; $250 \mathrm{~mm} \times 4,6 \mathrm{~mm}$ and LC-ABZ; $250 \mathrm{~mm} \times$ $4,6 \mathrm{~mm}$ ). Column temperature was $40^{\circ} \mathrm{C}$. 
The detection limits were $2 \mu \mathrm{g} \mathrm{kg}^{-1}$ for chlordecone in sediment and particulate matter, 2 $\mathrm{ng} \mathrm{I^{-1 }}$ for ametryn and simazine herbicides and $10 \mathrm{ng}^{-1}$ for aldicarb sulfone and sulfoxyde.

\subsection{Quality Assurance}

Quality assurance testing included the analysis of blanks, assessment of recoveries and reproducibilities and accuracy of the data relative to standard reference materials. The analytical laboratory participates regularly in international intercomparison exercises in the framework of the EU project QUASIMEME (Quality Assurance of Information for Marine Environmental Monitoring in Europe). The laboratory is under accreditation of COFRAC (French Comittee of Accreditation $N^{\circ}$ 100-1: water chemical analysis) based on ISO 17025. The laboratory is also approved for official control by the MEDD (French ministry of the sustainable environment. Approval $\mathrm{N}^{\circ} 8$, organic contaminant in brackish and salt waters including organochlorine, organophosphorous and triazine compounds). Following recovery data provided by the sorbent manufacturers, recoveries were only tested for carbamate compounds and not for other pesticides. The performances for recovery of aldicarbe sulfoxyde, aldicarbe sulfone and aldicarbe were $>60 \%,>80 \%$ and $>80 \%$ respectively.

\section{Results}

Results are presented in Table 3. At 3 of the 9 monitored sites, no pesticide contamination was detected under the described sampling and analysis conditions. These sites included the two sampling sites located along the salinity gradient of the Baie du Robert ( $6, S=25 \%$ and $7, S=35 \%$ ), Figure 1 , and the sampling site located in the estuary of the Carbet river (8) on the Caribbean Sea coast. Samples from the other 6 monitored sites samples were all contaminated, often by more than one compound. At these sites, the pesticides detected and quantified were chlordecone, aldicarb, and triazines. 
Table 3 : Levels of pesticides in water, suspended particulates and sediments from different locations of the Martinique Island in January and February 2002. Results are expressed as $\mu \mathrm{g} \mathrm{I}$ ${ }^{1}$ in water and $\mathrm{g} \mathrm{kg}^{-1}$ in particulate matter and sediment samples.

\begin{tabular}{|l|c|c|c|c|c|c|}
\hline & $\begin{array}{c}\text { chlordecone } \\
\text { (in suspended } \\
\text { matter) }\end{array}$ & $\begin{array}{c}\text { chlordecone } \\
\text { (in sediment) }\end{array}$ & $\begin{array}{c}\text { aldicarb } \\
\text { sulfoxide }\end{array}$ & $\begin{array}{c}\text { aldicarb } \\
\text { sulfone }\end{array}$ & simazine & ametryne \\
\hline Capot river & $<10$ & $<10$ & 0.043 & 0.083 & $<0.010$ & $<0.010$ \\
\hline Lorrain river & $<10$ & 44 & $<0.030$ & $<0.030$ & $<0.010$ & $<0.010$ \\
\hline Galion river & 52 & $<10$ & 0.052 & 0.032 & 0.016 & 0.017 \\
\hline Cacao river & 22 & $<10$ & $<0.030$ & $<0.030$ & 0.015 & 0.010 \\
\hline $\begin{array}{l}\text { Baie du } \\
\text { Robert (25\% } \\
\text { sea water) }\end{array}$ & $<10$ & $<10$ & $<0.030$ & $<0.030$ & $<0.010$ & $<0.010$ \\
\hline $\begin{array}{l}\text { Baie du } \\
\text { Robert (35\% } \\
\text { sea water) }\end{array}$ & $<10$ & $<10$ & $<0.030$ & $<0.030$ & $<0.010$ & $<0.010$ \\
\hline $\begin{array}{l}\text { Du François } \\
\text { river }\end{array}$ & 57 & 38 & $<0.030$ & $<0.030$ & 0.018 & $<0.300$ \\
\hline Lézarde river & 45 & 31 & $<0.030-$ & $<0.030$ & $<0.010$ & $<0.010$ \\
\hline
\end{tabular}

\subsection{Chlordecone}

Levels of each compound found within this study in Martinique were compared with concentrations reported for the same or closely - related compounds from mainland France.

In Martinique, chlordecone was frequently found in particulate matter isolated from river water and sediments. It was quantified in sediment samples from the Lorrain $(1,44 \mu \mathrm{g} \mathrm{kg}$ $\left.{ }^{1}\right)$, François $\left(4,38 \mu \mathrm{g} \mathrm{kg}^{-1}\right)$, and Lézarde $\left(9,31 \mu \mathrm{g} \mathrm{kg}^{-1}\right)$ rivers, as well as in particulate matter samples collected in the plume of the François $\left(4,57 \mu \mathrm{g} \mathrm{kg}^{-1}\right)$, the Galion $(3,52 \mu \mathrm{g}$ $\left.\mathrm{kg}^{-1}\right)$, Lézarde $\left(9,45 \mu \mathrm{g} \mathrm{kg}^{-1}\right)$ and Cacao $\left(5,22 \mu \mathrm{g} \mathrm{kg}^{-1}\right)$ rivers. Although chlordecone has never been used in mainland France, comparisons can be made with DDT, another OC insecticide with a similar biogeochemical behaviour. Chlordecone levels in sediment samples from Martinique were far greater than those measured for DDT in mainland France, where DDT levels in sediment generally range between 0 and $2 \mu \mathrm{g} \mathrm{kg}^{-1}$. The chlordecone levels were also much higher than DDT levels measured on the French Mediterranean coast, where they reach $10 \mathrm{\mu g} \mathrm{kg}^{-1}$ (RNO, 1998). 


\subsection{Carbamates}

Carbamates were detected in the dissolved phase samples from the northeastern part of the island. Aldicarb metabolites (sulfone and sulfoxide) were found in the plumes of the Capot (2) and Galion (3) rivers. Levels reached 0.043 and $0.052 \mu \mathrm{g} \mathrm{I}^{-1}$ for the sulfoxide metabolite and 0.083 and $0.032 \mu \mathrm{g} \mathrm{I}^{-1}$ for the sulfone metabolite in these rivers respectively. Although aldicarb is not used in mainland France comparisons could be made with related compounds such as carbofuran and carbaryl. These compounds are rather regularly found in streams and rivers and are present at concentrations of the order of $0.020 \mu \mathrm{g} \mathrm{I}^{-1}$. Carbofuran levels in the Seudre river of up to $0.200 \mu \mathrm{g} \mathrm{I}^{-1}$ were observed in May 2001, while carbaryl levels of $0.250 \mu \mathrm{g} \mathrm{I}^{-1}$ in the Vilaine river were reported in 1997 (GRAP, 2002. CORPEP, 2000, 2001).

\subsection{Triazines}

Triazines partition primarily to the dissolved phase. Simazine and ametryn were detected in the Galion (3), François (4), and Cacao (5) rivers. Levels of ametryn measured in the François (4) river, in brackish water $(S=11 \%)$, were high $\left(0.300 \mu \mathrm{g} \mathrm{I}^{-1}\right)$. Existing data on simazine levels in European estuaries show that concentrations found in Martinique and mainland France are of the same order of magnitude, i.e. a few tens of nanograms per liter. This is the case for the estuaries of the Sèvre Niortaise $\left(0.030 \mu \mathrm{g} \mathrm{I}^{-1}\right)$ and the Charente $\left(0.040 \mathrm{~m} \mathrm{I}^{-1}\right)$ rivers. In other European estuaries, simazine levels can reach higher values, e.g. up to $3 \mu \mathrm{g} \mathrm{I}^{-1}$ (Tauler et al., 2001. Garmouma et al., 2001. Drevenkar et al., 2004).

\section{Discussion}

This study builds upon 2 earlier surveys carried out in the upstream reaches of the rivers of Martinique. In 1999 and 2001, the DIREN conducted three surveys based on samples collected at 33 sites located in the rivers of Martinique. Nineteen pesticide active ingredients were identified and found to be present at various concentrations and frequencies (DIREN, 2001). The DIREN reported the recurring presence of chlordecone in waters of the Galion (1.20 $\mathrm{g} \mathrm{I} \mathrm{I}^{-1}$, in October 2000), Rouge (2.13 $\mathrm{g} \mathrm{I}^{-1}$, in August 2001) and Pocquet $\left(2.07 \mathrm{~g} \mathrm{I}^{-1}\right.$, in August 2001) rivers. These rivers are located in the north and middle-east parts of the island, very close to the banana fields. Contamination of river waters by chlordecone may reflect the presence of residual levels of this compound in treated soils. Although the use of chlordecone has been prohibited since 1994, levels reaching $5000 \mathrm{~g} \mathrm{~kg}^{-1}$ were recorded in the soils of the Gradis farm located near the river Rouge in August 1999 (DSDS, 2001).

The assessment of river water quality conducted by the DSDS showed that 36 pesticide active ingredients were present in all drinking water sources. The insecticide chlordecone was ubiquitous, being found in $95 \%$ of samples collected by the DSDS from January 1999 to May 2000 and in $100 \%$ of samples in June and July 2000, together with the $\mathrm{HCH}$ beta, another prohibited organochlorine insecticide. The highest values were observed in the Capot river, with a maximum level of $3 \mu \mathrm{g} \mathrm{I}^{-1}$ in the Gradis source (unfiltered water). Chlordecone still chronically contaminates most water resources, notably the drinking water inlet of the Capot river. Chlordecone was also found at levels reaching $2.51 \mathrm{\mu g} \mathrm{I}^{-1}$ in the Rouge river and $2.13 \mu \mathrm{g} \mathrm{I}^{-1}$ in the Pocquet river (unfiltered water). The following herbicides were also identified: bromacil, diuron, simazine, atrazine, and ametryn. In August 2001, (diuron $\left(2.47 \mu \mathrm{g} \mathrm{I}^{-1}\right)$ was detected in the François river and ametryn (1.14 $\mu \mathrm{g}^{-1}$ ) in the Pilote river. In the DSDS surveys, ametryn and simazine were present in $16 \%$ and $13 \%$ of samples, respectively.

Aldicarb is rapidly degraded. However, according to the DSDS surveys, the presence of its more stable metabolites was frequently detected. Aldicarb sulfone concentrations, measured at the drinking water inlet of the Capot river, reached $0.162 \mathrm{\mu g}^{-1}$ in June and July 2000. The water quality survey of the Capot river also revealed the presence of the insecticides oxamyl and cadusafos. Runoff of water from an area of cropland treated with aldicarb was analyzed by the Centre de Coopération Internationale en Recherche 
Agronomique pour le Développement (CIRAD) in 1999 (CIRAD/IRD, 2001). Results showed that aldicarb sulfoxide and aldicarb sulfone levels were 11.5 times higher than aldicarb levels 10 days after treatment.

No organophosphorous compounds were detected during the current study, despite terbufos, cadusafos, isazofos, and phenamiphos accounting for 700 of the 1816 metric tons of insecticides imported in 1998. The DSDS reported the presence of tetrachlorvinphos and cadusafos, while the DIREN reported the presence of methyl parathion. The biogeochemical behaviour of these compounds is complex, and understanding this requires a better knowledge of the metabolism of these neurotoxic molecules.

Fungicides were not detected in the current study. The monitoring network implemented by the DIREN recorded the presence of the fungicides tebuconazole, propiconazole, and thiabendazole at levels of nearly $1 \mathrm{\mu g} \mathrm{I}^{-1}$ in the north-eastern part of the island in March 2000.

Chlordecone is considered hazardous to the aquatic environment and human health due to its stability, persistence and potential to bioaccumulate in the food chain (WHO, 1984). Its bioconcentration factor can reach 9,350 in the oyster Crassostrea virginica, 11,425 in the shrimp Palaemonetes pugio, and 16,600 in the fathead minnow Pimephales promelas (Bahner et al., 1977 in WHO, 1984. Huckins et al., 1982). The $\mathrm{LC} \mathrm{SO}_{96}$ for the blue crab (Callinectes sapidus) is $210 \mathrm{Mg} \mathrm{I}^{-1}$, and $\mathrm{LC5O}_{48}$ for the brown shrimp Paeneus aztecus is $85 \mathrm{mg}^{-1}$ (EPA, 2000). Chlordecone is acutely toxic to the fathead minnow and sea lamprey with $\mathrm{LC}^{2} 0_{96}$ values of $69.5 \mu \mathrm{g} \mathrm{I}^{-1}$ and $414 \mu \mathrm{g} \mathrm{I}^{-1}$, respectively (EPA, 2000; Mallatt and Barron, 1988). Sublethal effects start appearing at much lower concentrations in long-term (36 day) exposure experiments. Hansen et al. (1976, in WHO, 1984) reported reduced growth of juvenile sheepshead minnows (Cyprinodon variegatus) following exposure to $0.08 \mu \mathrm{g} \mathrm{I}^{-1}$ chlordecone. Goodman et al. (1982) showed that the lethal concentration in sheepshead minnow embryos was $0.02 \mu \mathrm{g} \mathrm{I}^{-1}$ after a 21-day exposure. Chlordecone has high estrogenic activity, i.e. it can affect the reproductive system in many species including humans (Okubo et al., 2004. Donohoe and Curtis, 1996). Chlordecone was also shown to be carcinogenic in trout (Donohoe et al., 1998) and rats (Guzelian et al., 1992). According to the International Agency for Research on Cancer (WHO,1979), chlordecone is "possibly carcinogenic to humans" and is therefore considered as a Group 2B compound.

Aldicarb, a highly toxic pesticide (WHO, 1991) and its two main metabolites do not accumulate in the successive trophic levels of the food chain. The $\mathrm{LC} \mathrm{O}_{96}$ for many fish species ranges between 80 and $600 \mu \mathrm{g} \mathrm{I}^{-1}$ (Mayer and Ellersleck, 1986, in WHO, 1991. Mayer, 1987, in WHO, 1991), but the LOEC (lowest observed effects concentration) has been shown to be as low as $4.5 \mu \mathrm{g} \mathrm{I}^{-1}$ for the fathead minnow (Moore et al.,1998). The same authors showed that crustaceans are much more sensitive to aldicarb, as shown by a LOEC of $0.5 \mu \mathrm{g} \mathrm{I}^{-1}$ in the water flea Daphnia magna. Bivalve molluscs are apparently insensitive to the presence of this molecule in their environment $\left(\mathrm{LC} \mathrm{CO}_{48}\right.$ for oysters is $8,800 \mu \mathrm{g} \mathrm{I}^{-1}$, Mayer, 1987, in WHO, 1991). Aldicarb is not considered carcinogenic. As is the case with organophosphorous insecticides, aldicarb and its metabolites are acetylcholinesterase (AChE) inhibitors and as such are considered neurotoxic. Moreover, salinity appears to be an aggravating factor for the neurotoxic effect of aldicarb. El-Alfy and Schlenk (1998) established a direct correlation between salinity and aldicarb toxicity to the medaka fish, which may be due to a higher absorption of the compound and a greater production of the suloxide metabolite at higher salinity. Since january 2003 aldicarb uses were bounded in the French West Indies.

Portman and Wilson (1971) report the $\mathrm{LC} \mathrm{CO}_{48}$ for the triazine ametryn in the common shrimp (Crangon crangon) at between 33 and $100 \mathrm{~g} \mathrm{I} \mathrm{I}^{-1}$. Fish, on the other hand, appear to be less sensitive: the $\mathrm{LC} \mathrm{O}_{48}$ was estimated at $5,800 \mu \mathrm{g} \mathrm{I}^{-1}$ for the sheepshead minnow, $5,000 \mu \mathrm{g} \mathrm{I}^{-1}$ for the medaka fish, and $5,700 \mu \mathrm{g} \mathrm{I}^{-1}$ for the fathead minnow (EPA, 2000). Simazine toxicity is of the same order of magnitude. $\mathrm{LC} \mathrm{SO}_{48}$ values were estimated at $10,000 \mathrm{mg} \mathrm{I}^{-1}$ for the European green crab (Carcinus maenas) and $100,000 \mu \mathrm{g} \mathrm{I}^{-1}$ for the common shrimp. Hashimoto and Nishiuchi (1981) reported a $\mathrm{LC5O}_{48}$ of $10,000 \mathrm{gg} \mathrm{I}^{-1}$ for 
the medaka fish. According to the EPA (2000), $\mathrm{LC} \mathrm{SO}_{96}$ for the sheepshead minnow is $6,400 \mu \mathrm{gl}^{-1}$.

Triazines are potent photosystem II inhibitors and ametryn is known to impact photosynthesis of the endosymbiotic zooxanthellae of corals at low $\left(\mathrm{ng} \mathrm{I}^{-1}\right)$ concentrations (Jones, 2005). Simazine has also been shown to impact coral zooxanthellae photosynthesis, although it appears to be less toxic when compared to ametryn and diuron (Jones, 2005). Following Owen et al. (2002), any contaminant that inhibits symbiont photosynthesis could undermine the coral reef with serious ecological consequences. These authors show that the s-triazine herbicide Igarol 1051, which has a mode of action similar to simazine and other triazines although it is used as an antifouling compound, was found to be highly toxic to isolated zooxanthellae at concentrations as low as $0.063 \mu \mathrm{g} \mathrm{I}^{-1}$. A recent study (Jones and Kerswell, 2003) on the effects of herbicides on symbiotic dinoflagellates within the host tissues of the coral Seriatopora hystrix reports that the concentration of ametryn required to reduce chlorophyll content by $50 \%$ was $1.7 \mathrm{\mu g} \mathrm{I}^{-1}$. Herbicides were also correlated with severe damages of the mangrove trees in the NE region of Australia (Duke et al., 2005)

Data reported herein were obtained from samples collected after a 5 month period characterized by daily tropical rainfall events. Rainfall during the 2001-2002 winter season was, however, exceptional in terms of duration. The dry season usually lasts from October to June, however, in December 2001 precipitation reached $240 \mathrm{~mm}$ (the monthly average for 2001 was $117 \mathrm{~mm}$ ). For efficiency/economic reasons, pesticide application is limited during the rainy season. The observed precipitation may have caused a significant leaching of pesticides from soils. Consequently, the most soluble molecules, such as fungicides and many herbicides, may have been readily transported to coastal waters and dissipated, which may account for the fact that they were not detected in this study during January and February. Under such conditions, identification of simazine and ametryn in surface waters may suggest recent application. For the same reasons, maximal potential pesticide concentrations within the plumes may have been missed. Only compounds such as chlordecone, which binds more readily to soil particles, are leached in a more regular way throughout the erosion process of the catchment area. Data reported in this study may underestimate the pesticide loads to the marine environment.

\section{Conclusions}

The intensive use of pesticides for many years has led to widespread contamination of rivers and streams in Martinique. As surface water contamination had been previously reported by the DIREN and the DSDS, further investigations were warranted to try to determine whether the coastal environment had been affected. Samples collected in the estuaries of 7 rivers identified a number of compounds entering the marine environment. An organochlorine insecticide, chlordecone, was found to be widely distributed. Metabolites of aldicarb (a carbamate nematicide), and two triazines herbicides (ametryn and simazine), were also identified in the plumes of these rivers. Levels found in water and sediment samples from the coastal areas of Martinique, when compared with those found in mainland France, showed that contamination levels were similar for carbamates and triazines, but that chlordecone concentrations in suspended matter and sediment samples were far greater in Martinique than, for example DDT levels in mainland France. Chlordecone is a carcinogenic and bioaccumulating pesticide with a strong endocrine disruption potential. Monitoring of this compound should therefore be one of the priorities of any pollution monitoring network such as the Réseau National d'Observation, which has been implemented in mainland France. Use of chlordecone has been prohibited since 1993, but as chlordecone appears to be ubiquitous, important areas of cropland may still contain residual contamination today. There is a high risk that runoff and seeping water will continue to contaminate the aquatic and marine environments of the island for years to come. Considering the fact that chlordecone is extremely stable and given the lipophilic properties of this molecule, as well as its capacity to bioaccumulate, transfer of this compound to other trophic levels of the food chain, notably marine species, such as 
ish and crustaceans, which are consumed in large quantities by the local population, should be investigated.

Given reports of contamination of both rivers and their coastal plumes by herbicides in this and previous studies and growing evidence of the low level effects of these chemicals on coral photosynthesis, further investigation of the distribution of these herbicides and their impacts in the reef ecosystems adjacent to catchments with significant agricultural activity in Martinique is recommended.

\section{References :}

CIRAD/IRD. 2001. Etude du transfert de molécules nématicides-insecticides à l'échelle de la parcelle. 10 p. CIRAD. Fort-de-France. Martinique Island. France.

CORPEP. 2000. Etude de la contamination des eaux superficielles de Bretagne par les produits phytosanitaires. Rapport annuel 1999. 25p. Préfecture de la Région Bretagne. Rennes. France.

CORPEP. 2001. Etude de la contamination des eaux superficielles de Bretagne par les produits phytosanitaires. Rapport annuel 2000. 25p. Préfecture de la Région Bretagne. Rennes. France.

DIREN, 2001. Le suivi de la contamination des rivières de la Martinique par les produits phytosanitaires. Bilan à l'issue des trois premières campagnes de mesure. $12 \mathrm{p}$. DIREN, Fortde-France. Martinique Island. France.

Donohoe, R.M., Curtis, L. R. 1996. Estrogenic activity of chlordecone, o,p<prime>-DDT and $o, p<$ prime $>$-DDE in juvenile rainbow trout: induction of vitellogenesis and interaction with hepatic estrogen binding sites. Aquatic Toxicology. 36 (1-2) : 31-52

Donohoe, R.M., Quan-Zhang, N., Siddens, L.K., Carpenter, H.M., Hendricks, J.D., Curtis, L.R. 1998. Modulation of 7,12-dimethylbenz[a]anthracene disposition and hepatocarcinogenesis by dieldrin and chlordecone in rainbow trout. Journal of Toxicology and Environmental Health Part. Volume 54, Number 3.

Drevenkar, V., Fingler, S., Mendas, G., Stipicevic, S., Vasilic Z. 2004. Levels of atrazine and simazine in waters in the rural and urban areas of north-west Croatia. International Journal of Environmental Analytical Chemistry. 84 (1-3) :207-216.

DSDS, 2001. Pesticides et alimentation en eau potable en Martinique. Etat des lieux et position sanitaire. Bilan actualisé en octobre 2001. 11 p. Direction de la Santé et du développement Social de la Martinique. Fort-de-France. Martinique Island. France.

Duke, N. C. , Bell, A. M. , Pederson, D. K. , Roelfsema, S. M. , Nash S. B. 2005. Herbicides implicated as the cause of severe mangrove dieback in the Mackay region, NE Australai: consequences for marine plant habitats of the GBR World Heritage Area. Marine Pollution Bulletin. 51:308-324.

El-Alfy, A. , Schlenk, D. 1998. Potential mechanisms of the enhancement of aldicarb toxicity to japanese medaka (Oryzias latipes) at high salinity. Toxicology and applied pharmacology. 152, 175-183.

EPA, 2000. US Environmental Protection Agency. Pesticide Ecotoxicity Database (Environmental Effects Database (EEDB)). Office of Pesticide Programs. Environmental Fate and Effects Division, U.S.EPA, Washington, D.C. AQUIRE Reference No: 344

Garmouma M., Blanchoud H., Teil M.J., Blachard M and Chevreuil M. 2001. Triazines in the Marne and the Seine rivers (France) : Iongitudinal evolution and flows. Water, Air and Soil Pollution. 132 (1-2) : 1-17. 
Goodman, L.R., D.J. Hansen, C.S. Manning, Faas, L.F. 1982. Effects of Kepone on the Sheepshead Minnow in an Entire Life-Cycle Toxicity Test Arch.Environ.Contam.Toxicol. 11:335342 .

GRAP, 2002. Réseau régional de suivi de la qualité des eaux vis à vis des produits phytosanitaires. Années 1999, 2000 et 2001. 74 .p DIREN Poitou-Charente. Poitiers. France.

Guzellian, P.S., Chambers, P.L., Chambers, C.M., Bolt, H.M., Preziosi, P., 1992. The clinical toxicology of Chlordecone as an example of toxicological risk assessment for man. Toxicology from discovery and experimentation to the human perspective. Toxicology-letters.; 64-65 : 589596

Hashimoto, Y., Nishiuchi, Y. 1981. Establishment of Bioassay Methods for the Evaluation of Acute Toxicity of Pesticides to Aquatic Organisms. Journal of Pesticide Sciences. 6(2):257-264.

Huckins, J.N., Stalling, D.L., Petty, J.D., Buckler, D.R., Johnson, B.T. 1982. Fate of Kepone and mirex in the aquatic environment. Journal of Agriculture and Food Chemistry. $30: 1020-1027$.

IARC. 1979. Some halogenated hydrocarbons. International Agency for Research on Cancer. Monographs on the evaluation of the carcinogenic risk of chemicals to human. Vol. 20. Geneva. Switzerland.

Jones, R. (2005) The ecotoxicological effects of Photosystem II herbicides on corals. Marine Pollution Bulletin (in press)

Jones, R., Kerswell A. 2003. Phytotoxicity of photosystem II (PSII) herbicides to coral. Marine Ecology Progress Series. Vol. 261:149-159.

Mallatt, J., Barron, M.G. 1988. High Tolerance of Lampreys to Kepone Toxicity. Archives of Environmental Contamination and Toxicology. 17(1):73-80.

Moore, M.T., Huggett, D.B., Gillespie, W.B. Jr., Rodgers, J.H. Jr., Cooper, C.M. 1998. Comparative Toxicity of Chlordane, Chlorpyrifos, and Aldicarb to Four Aquatic Testing Organisms. Archives of Environmental Contamination and Toxicology. 34(2):152-157

Okubo, T., Yokoyama, Y., Kano, K., Soya, Y., Kano, I. 2004. Estimation of estrogenic and antiestrogenic activities of selected pesticides by MCF-7 cell proliferation assay. Archives of Environmental Contamination and Toxicology. 46 (4) : 445-453.

Owen, R., Knap A., Toaspern M., Carbery K. 2002. Inhibition of coral photosynthetis by the antifouling herbicide Irgarol 1051. Marine Pollution Bulletin 44: 623-632.

Portmann, J.E., Wilson, K.W. 1971. Shellfish Information Leaflet No.22 (2nd Ed.), Ministry of Agriculture Fishery and Food, Fishery Laboratory, Burnham-on-Crouch, Essex, and Fish Experimental Station, Conway, North Wales :12 p. Burnham-on-Crouch. United Kingdom.

R.N.O, 1998. Réseau National d'Observation de la qualité du milieu marin. Surveillance du milieu marin. Travaux du RNO. IFREMER et Ministère français de l'aménagement du Territoire et de l'Environnement. 50 p. Nantes. France.

Tauler, R., Azevedo, D., Lacorte, S., Cespedes, R., Viana, P. Barcelo, D. 2001. Organic pollutants in surface waters from Portugal using chemometric interpretation. Environmental Technology. 22 (9) :1043-1054.

WHO, 1984. Environmental Health Criteria 43. Chlordecone. World Health Organization. 57 p. Geneva. Switzerland.

WHO, 1991. Environmental Health Criteria 121. Aldicarb. World Health Organization. 130 p. Geneva. Switzerland. 